\title{
METADISCOURSE MARKERS WRITTEN IN INTRODUCTION SECTION OF FINAL PROJECT OF UNIMUS EFL LEARNERS
}

\author{
Siti Aimah \\ English Education Department, Faculty of Foreign Language and Culture \\ Universitas Muhammadiyah Semarang, Indonesia \\ E-mail: siti.aimah@unimus.ac.id \\ Dodi Mulyadi \\ English Education Department, Faculty of Foreign Language and Culture \\ Universitas Muhammadiyah Semarang, Indonesia \\ E-mail: dodi@unimus.ac.id \\ Muhimatul Ifadah \\ English Education Department, Faculty of Foreign Language and Culture \\ Universitas Muhammadiyah Semarang, Indonesia \\ E-mail: muhimatul@unimus.ac.id
}

\begin{abstract}
APA Citation: Aimah, S., Mulyadi, D., \& Ifadah, M. (2019). Metadiscourse markers written in introduction section of final project of Unimus learners. English Review: Journal of English Education, 7(2), 109-118. doi: 10.25134/erjee.v7i2.1717.
\end{abstract}

Received: 04-01-2019

Accepted: 13-04-2019

Published: 01-06-2019

\begin{abstract}
Metadiscourse marker is one of determining indicators of the quality of the writers' writing. Metadiscourse markers enable the writers to interact with the readers effectively. What commonly happens to many undergraduate students studying English as a foreign language is that they are not able to develop an engagement between themselves, their texts, and their readers. Thus, this study investigates the types of metadiscourse markers used by Unimus EFL learners in final project introduction sections, and markers that are frequently used by them in their writing. By using qualitative and quantitative research method, seven introduction sections of final project of Unimus EFL learners focusing on qualitative and qualitative research methods were chosen purposively. As result, the study revealed that in writing introduction sections, the students used various metadiscourse markers, including interactive resources (transitions, frame markers, endophoric markers, evidentials, and code glosses) and interactional resources (hedges, boosters, attitude markers, engagement markers, and self-mensions). Among those categories, interactive resources were found to be frequently used by the learners rather than interactional resources. It means that the writers tended to give attention to and guided the readers through the text by establishing their interpretations explicitly rather than involving the readers in the argument through the use of markers in interactional dimension.
\end{abstract}

Keywords: final project; interactional metadiscourse; interactive metadiscourse; introduction section; marker; metadiscourse; writing.

\section{INTRODUCTION}

Writing final project is crucial for undergraduate students as the fulfillment in obtaining their bachelor degree. It is undeniable for them to write their English report and paper in which their text should be understandable to the readers. In order to be understandable, their text should be coherent. Hence, it demands them to have the awareness on the text in order to make it comprehensible.

Writing a final project for EFL learners is regarded as a challenging activity in which the language used in the text is quite different from those coming from the other departments in which they have to present it in English. It demands them to provide the text that is easily recognized by the readers. Therefore, they should understand that there is a communication between the writer (through the text) and the readers in understanding the meaning/content. In fact, EFL learners are commonly not aware that in writing, it is required a good interaction between the writer and the readers in order the messages that the writer would like to convey could be understood by the readers. This condition happens even though writing course has been studied intensively from the early semester. Yet, their writing is commonly found incomprehensible to the readers. In writing, the learners, in this case, should build a communication through a cohesive and coherent text that enables the readers to have a better 
understanding of what the writer's intention. In order to understand the writer's intention, it is required metadiscourse markers which are basically used to negotiate meaning (Hyland, 2010).

Metadiscourse, which is principally used in both spoken and written texts, allows the writer to show the readers about the different parts of the text which are related and should be interpreted (Hyland, 2010). It is emphasized on the use of language which is not only simply used to convey information about the fact, but also to present information to others through the organization of the text. It means that in writing, the writer needs not only to express his/her feeling and/or experience, but also to interact intimately with the readers explicitly and implicitly through a cohesive and coherent text which enables the readers to grasp the writermeaning. It is in line with Hyland \& Tse (2004) who state metadiscourse is recognized as an important means of facilitating communication which support a writer's position and build a relationship with an audience through their texts. By using metadiscourse, besides making easier in organizing the texts, it could also be intended to help the readers decode the message (DafouzMilne, 2008), and engage the readers through the texts themselves (Hyland \& Tse, 2004).

In engaging the readers, the writer should make a communication. Metadiscourse is not only about the exchange of information, good or services, but also involves characters and attitudes of those who are communicating (Hyland, 2015). It means that language is an outcome of interaction of different people who express through language, and metadiscourse is the way to verbalize and construct the interaction. In communicating through the text in which the writer should involve in both creating and sharing meanings, the writer should write in two levels: on one level he/she should provide information about the subject matter of the text. It means that it is needed for expanding propositional content. On the other level, the writer needs not to add anything to the propositional content but he/she should help the readers to organize, interpret, evaluate, and react to such material through the use of metadiscourse (Hyland, 2010).

In a very recent study, Rustipa (2014) investigated metadiscourse in Indonesian EFL learners' persuasive text. It revealed that the occurrences of textual marker types in EFL learners' persuasive texts were similar to those considered as standard proficient writing (extract from BAWE corpus), while those of interpersonal marker types were different from the standard proficient writing. Kuhi and Mojood (2014) conducted a research about metadiscourse in newspaper genre: English and Persian editorials. It showed that the predominant metadiscourse category in editorials genre was interactional category and the predominant metadiscourse feature was attitude markers (a subcategory of interactional category). The differences between two editorials were attributed to cultural/linguistic backgrounds of both groups of editorialists.

In this study, two levels of metadiscourse markers proposed by Hyland (2015) were used: interactive and interactional metadiscourses. The list of the categories, their functions, and the examples are presented in Table 1.

For investigating the use of metadiscourse markers in EFL learners' final project of Unimus, particularly in writing introduction section, the study is limited on the writing of background of the study. In writing background of the study, the writer should clearly describe to the readers what is being researched and why in which it enables to have a communication intimately between the writer and the readers through the text. Hence, some research questions are proposed as follow:

1. What kinds of metadiscourse are used by Unimus EFL learners in writing introduction section?

2. What are metadiscourse markers frequently used by Unimus EFL learners in writing introduction section?

Table 1. Interactive and interactional metadiscourses adapted from Hyland (2015)

\begin{tabular}{lll}
\hline Category & \multicolumn{1}{c}{ Function } & \multicolumn{1}{c}{ Interactive Metadiscourse } \\
\hline Transition & $\begin{array}{l}\text { express semantic relation between main } \\
\text { clauses } \\
\text { refer to discourse acts, sequences, or text }\end{array}$ & in addition / but / thus / and \\
Frame Markers & ftages & finally / to conclude / my purpose is \\
Endophoric Markers & refer to information in other parts of the text & noted above / see Fig / in section 2 \\
Evidentials Markers & refer to source of information from other & according to X/(Y, 1990)/Z states
\end{tabular}




\begin{tabular}{|c|c|c|}
\hline Code Glosses & $\begin{array}{l}\text { texts } \\
\text { help readers grasp meanings of ideational } \\
\text { material }\end{array}$ & $\begin{array}{l}\text { namely /e.g. / such as / in other } \\
\text { words }\end{array}$ \\
\hline \multicolumn{3}{|c|}{$\begin{array}{r}\text { Interactional Metadiscourse } \\
\end{array}$} \\
\hline Hedges & $\begin{array}{l}\text { withhold writer's full commitment to } \\
\text { proposition }\end{array}$ & might / perhaps / possible / about \\
\hline Boosters & $\begin{array}{l}\text { emphasize force or writer's certainty in } \\
\text { proposition }\end{array}$ & $\begin{array}{l}\text { in fact / definitely / it is } \\
\text { clear that }\end{array}$ \\
\hline Attitude Markers & express writer's attitude to pro-position & $\begin{array}{l}\text { unfortunately / I agree / } \\
\text { surprisingly }\end{array}$ \\
\hline Engagement & explicitly refer to or build relationship with & consider / note that / \\
\hline Markers & reader & you can see that \\
\hline Self-Mentions & explicit reference to author(s) & I/we / my / our \\
\hline
\end{tabular}

\section{METHOD}

This research was employed by combining qualitative and quantitative research methods. The quantitative data were tabulated to explicate the use of metadiscourse markers, while qualitative data were analyzed to describe the types of metadiscourse markers found in the texts. The present research focuses on the use of metadiscourse markers in quantitative and qualitative method academic text written by English undergraduate students. There were seven introduction sections of four qualitative methods and three quantitative methods from different topics, including language teaching, translation, and language assessment written by different EFL learners. These final projects were selected from English Department of Universitas Muhammadiyah Semarang (Unimus) who successfully graduated in 2017.

The unit of analysis was metadiscourse markers in both interactive markers which covered transition, frame markers, endophoric markers, evidentials, and code glosses, and interactional markers which comprised hedges, boosters, attitude markers, engagement markers, and self-mentions.

The data were taken by identifying the use of metadiscourse markers proposed by Hyland (2015) from the students' writing. The markers found from the students' writing consisting of 5.363 words were classified by categorizing them into transitions, frame markers, endophoric markers, evidentials, and code glosses which were categorized into interactive dimension, and those which were hedges, boosters, attitude markers, engagement markers, and self-mentions were categorized into interactional dimension.

Those markers were then analyzed in detail to interpret based on some considerations of functional meaning and calculated to derive the frequency and percentage of using them in those words in which its function was to support the description.

Table 2. Titles of final project from which data were selected

\begin{tabular}{|c|c|c|c|c|}
\hline No & Authors & $\begin{array}{l}\text { Research } \\
\text { Method }\end{array}$ & Title & $\begin{array}{c}\text { Year of } \\
\text { Completion }\end{array}$ \\
\hline 1. & Haque, S. & Qualitative & $\begin{array}{l}\text { A Content Analysis of English Textbook } \\
\text { Related to Contextual Teaching and Learning }\end{array}$ & 2017 \\
\hline 2. & Kumala, B. P. & Qualitative & $\begin{array}{l}\text { An Analysis of Grammatical Errors on } \\
\text { Students' Writing }\end{array}$ & 2017 \\
\hline 3. & Paramitha, D. & Qualitative & $\begin{array}{l}\text { Students' Difficulties in Translating Idiomatic } \\
\text { Expressions from English into Indonesian }\end{array}$ & 2017 \\
\hline 4. & Zulfa, A. & Qualitative & $\begin{array}{l}\text { The Analysis of "Bahasa Inggris" Textbook } \\
\text { Seen from Its Quality }\end{array}$ & 2017 \\
\hline 5. & Ariyani, D. N. F. & Quantitative & $\begin{array}{l}\text { The Implementation of Explicit Instruction } \\
\text { (EI) and Self-Directed Learning (SDL) to } \\
\text { Teach Students Writing }\end{array}$ & 2017 \\
\hline 6. & Saputri, E. A. D. & Quantitative & $\begin{array}{l}\text { The Effectiveness of Peer Feedback } \\
\text { Technique and Magic Cards to Improve } \\
\text { Students' Speaking Skill }\end{array}$ & 2017 \\
\hline 7. & Solikhatun & Quantitative & $\begin{array}{l}\text { The Influence of Using Textless Comics and } \\
\text { Make a Match on Students' Writing of } \\
\text { Recount Text }\end{array}$ & 2017 \\
\hline
\end{tabular}


RESULTS AND DISCUSSION

Types of metadiscourse markers used by Unimus EFL learners

The finding reveals that metadiscourse markers, either interactive dimension or interactional dimension, perform in the students' writing introduction sections. In the use of metadiscourse markers, the markers of Interactive dimension mainly dominate in the students' writing rather than interactional dimension. Interactive resources help to guide the readers to interpret the text correctly (Suhono \& Haikal, 2018). It means that the writer needs to organize a text in anticipating the readers' needs and facilitating the readers by guiding them through the text itself (Cao \& $\mathrm{Hu}, 2014$; Wei, Li, Zhou \& Gong, 2016). The result of metadiscourse markers found in the students' writing of introduction sections could be seen in Table 3.
From Table 3, it could be seen that there are 637 metadiscourse markers found in 5.363 words produced by 7 students' writing of final project introduction sections which consist of 524 markers $(82.3 \%)$ in interactive dimension and 113 markers $(17.7 \%)$ in interactional dimension. It means that the use of metadiscourse markers in interactive dimensions which are dominated by the use of transitions (374 markers) is higher than interactional dimensions in which the highest marker used is hedges with the occurrence of 39 times.

The use of metadiscourse markers by the learners are realized to help the writers in connecting the clauses and/or emphasizing what they have written through the texts. It means that metadiscourse markers are very important for the learners in organizing the sentences into a cohesive and coherent text so that the readers get easier in grasping the meaning.

Table 3. Metadiscourse in Introduction Section Writing

\begin{tabular}{lcclcc}
\hline Category & Occurrence & Percentage & Category & Occurrence & Percentage \\
\hline Transition & 374 & $71.4 \%$ & Hedges & 39 & $34.5 \%$ \\
Frame Markers & 20 & $3.82 \%$ & Boosters & 21 & $18.6 \%$ \\
Endophoric Marker: & 27 & $5.15 \%$ & Attitude Markers & 15 & $13.3 \%$ \\
Evidentials & 33 & $6.30 \%$ & Engagement Markers & 17 & $15.0 \%$ \\
Code Glosses & 70 & $13.3 \%$ & Self-Mentions & 21 & $18.6 \%$ \\
Interactive & $\mathbf{5 2 4}$ & $\mathbf{8 2 . 3 \%}$ & Interactional & $\mathbf{1 1 3}$ & $\mathbf{1 7 . 7 \%}$ \\
\hline
\end{tabular}

\section{Metadiscourse markers frequently used by Unimus EFL learners}

In the EFL learners' introduction section writing, particularly in the interactive marker, the most frequent category of metadiscourse is transitions markers which comprise 374 markers (71.4\%). The use of transitional markers in writing, according to Wei, Li, Zhou \& Gong (2016) can be classified into three types, namely addition (e.g., moreover, in addition), comparison (e.g., similarly, in comparison) or contrast (e.g., however, by contrast), and inference (e.g., therefore, consequently). However, Hyland (2015) argues that transitions are commonly used to emphasize on the use of any conjunctions which are used to express the semantic relation between main clauses, such as in addition, but, thus, and, etc., and help interpret the intended information through the texts (Cao \& $\mathrm{Hu}, 2014)$.

At this point, transitions are the most frequently used by the learners considering that the use of conjunctions are usually taught by the English lecturers in teaching writing so that they are so familiar and used to practice with the use of them. It means that the learners have a good knowledge of transitions to be applied in their writing. The use of transitions in selected introduction sections writing could be seen in the following examples.

(1) Therefore, students are demanded to earn spoken and written products, such as short functional texts, transactional texts, essay, etc.

(2) Yet, it also requires knowledge and understanding to choose the closest and the most proper equivalence in target language to properly convey the message contained in source language into target language.

(3) However, the translator which in this case is students often encounters some difficulties during the translation process.

Those bold words, in the sentences (1), (2), and (3) indicate the use of transitions in the students' writing of introduction sections. The use of and and yet is a part of the example of transitions commonly used by the learners for expressing the relation between words, phrases, sentences, and clauses. Therefore and however which appear at the beginning of the sentence indicate result and contrast. The use of those transitions seems to be effective and good flow 
of communication between the writer and the readers through the text in order to be sensible and comprehensible.

The use of code glosses is in the second position of using the metadiscourse markers with the occurrence of $70(13.3 \%)$. It helps the readers to grasp the appropriate meanings of elements in the texts (Hyland, 2015). It also provides the information clearly about definition that is needed by the readers and/or gives the examples that refer to the things to be emphasized. In other words, code glosses are used to clarify what actually the writer's communicative purposes are. The markers represent a number of basic communication strategies used in the negotiation of meaning in different context. The markers usually used are namely, such as, for example, in other words, etc. The use of those markers is to explain and elaborate on meaning, and help readers in grasping the information (Wei, Li, Zhou, \& Gong, 2016). The followings are the examples of using the code glosses by the learners.

(4) However, figurative language is also used in formal writing such as article or news in magazines and newspaper.

(5) Teaching English must cover four language skills namely: listening, speaking, reading and writing. From the sentences (4), and (5), it could be seen the use of code glosses such as and namely is intended to rephrase, explain and elaborate what has been said by the writer so that the readers are able to recover what the writer's intended meaning is (Hyland, 2015). Code glosses are also required by the readers as guidance in interpreting, elaborating, and clarifying the examples needed (Dehghan \& Chalak, 2015). The use of code glosses makes the readers easier in getting their understanding about what they are reading through the text. It could be seen from the sentence (4) which describes clearly to the readers about the figurative language which is commonly used in formal writing by emphasizing such as article or news in magazines and newspaper. The other example could be seen in sentence (5) in which the writer mentions that teaching English must cover four language skills by emphasizing the use of namely for mentioning the skills covered.

The third one is evidentials which present source of information from other texts (Cao \& $\mathrm{Hu}, 2014$; Hyland, 2015). According to Wei, Li, Zhou, \& Gong (2016), there are two types of evidential markers: the integral and non-integral. Integral relates to a cited source as part of the reporting sentence, and the non-integral places a cited source within parentheses or via a superscript number leading to a footnote, endnote or bibliography. The use of evidentials is basically to strengthen what they argue referring to the source of information from other texts. In using the source of the information through the markers, the occurrence is 33 $(6.30 \%)$. It means that the learners have the knowledge for strengthening the information/statement written through the source of textual information by encoding them with the writing of according to $X,(Y, 2017), Z$ states, etc.

(6) According to Alufohai (2016: 62), grammar at the sentence level is fundamental for the writing of compositions in English language.

(7) As mentioned by Wright (2002: 10), translating idiom is considered to be difficult, since idiom cannot be translated as word for word.

(8) Some evidences of the positive role of the incorporation of comics into school reading practices in the early years is provided by the results of Marsh's study in two Sheffield schools in the United Kingdom (Marsh \& Millard 2000: 110).

The sentences (6), (7), and (8) are categorized into non-integral markers in which it refers to the use of a cited source within parentheses. The evidentials markers are used to express the evidence that the writers have for their statement. Those markers are required by the writers to refer to the information in other parts of the text. With the occurrence which achieves $6.30 \%$, it indicates that the learners do not use many of them to strengthen their statement. Their weakness of using evidential markers commonly deals with their knowledge of how to interpret what the sources state by relating to their own statements. It is understandable considering that the activity of writing is not much explored by them. That's why it is frequently found that the evidential markers used by the learners do not refer to the things that they mention.

The next rank is endophoric markers. According to Hyland (2015), endophoric markers refer to information that could be found in other parts of the text. The use of endophoric markers in introduction sections could be found as much as $27(5.15 \%)$ which are categorized into cataphoric and anaphoric (Wei, Li, Zhou \& Gong, 2016). Cataphoric refers to announcement, advance labelling, preview; and anaphoric deals with reminder, recapitulation, and review. 
(9) The statement above is reinforced by the description of pre-observation in English Education Department of University of Muhammadiyah Semarang in the academic year 2016-2017.

(10) Based on that condition, the students need a stimulus to improve their English speaking performance.

(11) Based on the fact above, I would like to find out the difficulties encountered by students in translating idiomatic expression from English into Indonesian by first knowing the quality of their translation product.

From sentences (9), (10), and (11), mostly the writers want to emphasize on the use of endophoric markers referring to reminder, recapitulation, and review. The writers commonly have collected the information required to strengthen their arguments. Therefore, the use of based on that condition and based on the fact above shows that the writers would like to make their readers sure with the intended data and/or information in which it is also to provide/strengthen their supporting arguments (Suhono \& Haikal, 2018).

The use of frame markers such as finally, to conclude, my purpose is, first, etc. is in the last position in which they are only used 20 times $(3.82 \%)$. Frame markers are used to organize the texts for the readers (Cao \& Hu, 2014). The use of them enables the readers to understand clearly about the items used to sequence, label text stages, announce discourse goals, and indicate topic shift (Hyland, 2015). Those are needed by the writers in order to make their writing good in order/shift.

Frame markers can be further classified into four subtypes according to their functions: sequencers, topicalizers, discourse-labels, and announcers. Sequencers (e.g., first, second) are used to structure the text into sequences; topicalizers (e.g., in regard to, concerning) to signal the shift from one topic to another; discourse-labels (e.g., in summary, thus far) to mark the stages of textual development; and announcers (e.g., aim to, seek to) to indicate discursive purposes (Cao \& Hu, 2014; Wei, Li, Zhou, \& Gong, 2016).

(12) The first category is grammatical category which related to the form, aspect, and genus of any unit of language.

(13) Finally, teachers have responsibility to choose a textbook for students to fit with appropriate teaching and learning model.

(14) The purpose of this research is to find out the importance of the correlation between content to contextual teaching and learning.
Those markers (see (12), (13), and (14)) help the readers to comprehend the writers' emphasis of their writing through the sequences, goals, and/or topic shift. It is not easy for the learners in using those markers. It could be seen from the frequency of using them in their whole writing in which the most frequently used is when they mention the purpose of conducting their research. It indicates that their understanding of using the markers is still low.

Meanwhile, in the interactional marker, hedges are the most frequently used by the learners in writing their introduction sections with the frequency of 39 times (34.5\%). Hedges play an important role in conveying the writer's message. It involves readers collaboratively in the argument by alerting them to the author's own perspective toward both information and readers themselves (Hyland, 2010; Hyland \& Tse, 2004; Wei, Li, Zhou, \& Gong, 2016). The use of hedges in academic writing is to present propositional information categorically (Hyland, 2015). It means that there is a relationship and interaction between the writer and the readers through the use of certain expressions. It is essentially intended to evaluating and engaging, influencing the degree of intimacy, the expression of attitude, the epistemic judgments, the commitments, and the degree of reader involvement. In detail, Wei, Li, Zhou, \& Gong (2016) mention that hedges can be realized by such lexico-grammatical forms as epistemic modal verbs (e.g., might, could, may), lexical verbs (e.g., suggest, appear, claim), adjectives and adverbs (e.g., plausible, probably, perhaps), nouns (e.g., likelihood, possibility), and other linguistic expressions for marking qualification (e.g., in general, to some extent). The followings are the examples of using the hedges commonly used to mark the writers' reluctance.

(15) If the teacher does not realize about students' mistakes and errors, those mistakes and errors may occur repeatedly because they do not have the correction.

(16) Translator should understand the meaning first before translating the whole meaning.

(17) Besides that, she also applied self-directed learning (SDL) in which the users have a role as decision makers to determine their own learning and accept their responsibility intact, though they may need help and advice from the teacher.

From (15), (16), and (17), it could be seen that there are some types of hedges used by the writers. The use of hedges shows the degree of tentativeness, possibility, and/or politeness used 
by the writers in their texts (Rustipa, 2014). The possibility is built by the writer through the text, such as the use of may (see sentence (17) in which the writer is not sure whether or not the users need help and advice from the teacher. The use of should which is frequently used by the learner in their writing, is intended to give suggestion to the readers dealing with certain information. In sentence (17), the writer intends to give advice to the translator in which it is important for him/her to know the meaning before translating the text. Meanwhile, about presents the information emphasized by the writers about what they are writing.

The next one is the use of boosters that can only be found as much as 21 times $(18.6 \%)$ by encoding the use of in fact, definitely, it is clear that, etc. in which the point is to emphasize and/or to express the writer's certainty (Hyland, 2015). The use of boosters can be realized by epistemic modal verbs (e.g., must), lexical verbs (e.g., show, demonstrate, prove), adjectives and adverbs (e.g., undisputed, undoubtedly), nouns (e.g., fact, certainty), and other emphatic expressions (e.g., without a doubt).

The use of boosters also allows the readers to find out about the writer's opinion (Rustipa, 2014). The use of boosters in writing introduction section in which it is the second position of using the markers in the interactional dimension is to emphasize their certainty. Those markers indicate that the writers are assertive enough in expressing the certainty.

(18) It means that writing requires capability at organizing and combining information into cohesive and coherent paragraphs and texts in order to be understandable.

(19) On the other hand, the fact in class showed that the students had problems with their writing skill and difficulties to generate and organize their ideas in the written-form.

(20) From the phenomena above, it showed that the second and fourth semester students of English Education Department of University of Muhammadiyah Semarang had problems in grammar.

Sentence (18) which uses the marker of it means that refers to the affirmation toward what the writer has. She/he would like to emphasize of something that she/he has by making a conclusion of the explanation given. It makes the readers easier in understanding of what she/he has written in the text. The use of marker the fact (sentence (19)) is also used by the writer to present the condition in real (contrary term). By using the marker, it will help the readers to wonder the two different things compared. Sentence (20) with the use of it showed that emphasizes on the writer's proposition. The writer wants the readers know that the evidence to support her/his statement before.

Meanwhile, self-mentions in which they explicitly refer to the author(s) are more frequently used by the learners in asserting their position with the occurrence of 21 (18.6\%). They are used to show the extent to which the author presence in terms of first-person pronouns (e.g., we, I) and possessives (e.g., our, my) (Hyland, 2015). The use of self-mention markers could be seen in the following examples.

(21) Based on the fact above, I would like to find out the difficulties encountered by students in translating idiomatic expression from English into Indonesian by first knowing the quality of their translation product.

(22) I use textless comics as a media and make a match as a model of learning.

(23) The reason above encourages me to do evaluation toward the worthiness of content that is containing in English Textbook Contextual Teaching and Learning.

Self-mentions which are used by the learners are to show their self-affirmation from the readers. It could be seen clearly from the firstpronoun used of $I$ and $m e$ in the sentences (21), (22), and (23). The use of the markers shows explicitly their position/their function as the authors in their writing.

The next is the engagement markers, such as consider, note that, you can see that, etc. At this point, the writers do not want to involve more the readers as participants in the text through second-person pronouns, imperatives, and questions forms (Hyland, 2015). Considering their difficulties in using those markers, the occurrence in their writing of introduction section is only 17 times $(15 \%)$.

(24) We cannot deny that most of material commonly used by teachers in learning process is taken from textbook as an instructional media.

(25) Considering the importance of translation, this subject is included as a course that has to be taken by English department students in the university level.

Engagement markers which are intended to build relationship with the readers (Hyland, 2015) could not be found easily in the learners' writing. It is clearly seen from the total of 5.363 words produced, only 5 learners who use the markers, while the rest, 2 learners do not use the markers in their writing. In sentence (24), the 
writer uses we cannot deny that in his sentence means that he would like to involve the readers as the participant in the text through secondperson pronoun we in which both the writer and the audience cannot avoid the use of materials in the process of learning which are taken from textbook. The marker considering is used by the writer to make the readers focus their attention on the importance of translation to the English learners as a course to be taken.

The frequency of using attitude markers which is used to express writer's attitude to proposition: conveying surprise, obligation, agreement, importance, etc. (Hyland, 2015) is the lowest among others. The markers can adopt the form of deontic verbs (must, have to, should...), attitudinal adverbs (interestingly, surprisingly...), adjective constructions (it is difficult, impossible, desirable, unfortunate...), cognitive verbs (I think, I believe...), and other expressions conveying stance or evaluation (e.g., what is important, it is necessary) (Wei, Li, Zhou, \& Gong, 2016). The use of obligation such as must is mainly used by the learners in which it is emphasized to do something. Dealing with this point, the occurrence of using the markers in their writing is 15 times $(13.3 \%)$.

(26) The learners must apply the five general components of the writing process, they are content, form, grammar, style and mechanic.

(27) It is not surprising that textbook often becomes the only supporting instrument for the teacher to run the lesson in classes.

(28) First, textbook are relatively easy to get in the market, provide a guide or road map for the learner which offers expected behaviors that he had to perform to find and are commercially provided.

Numbers of (26), (27), and (28) indicate the variety of using attitude markers in the text. However, among the presence of those markers, the learners dominantly use obligation, such as must, have to, and had to rather than the others as seen in sentence (26) and (28). Meanwhile, for indicating surprise, only a few of them use the marker in their writing.

From those findings, it is clearly seen that the total occurrence of metadiscourse markers in introduction sections of Unimus EFL learners is 637 in which the interactive metadiscourse usage is higher (524) than interactional metadiscourse one (113). This finding is an alignment with the previous findings (Anwardeen, Luyee, Gabriel \& Kalajahi, 2013; Zakaria \& Malik, 2017) which showed that undergraduate students tended to use interactive metadiscourse (textual metadiscourse) rather than interactional metadiscourse (interpersonal metadiscourse). It means that the learners, in this case, tend to interpret the messages explicitly through the text rather than involving the readers through the arguments given. It is understandable in which culture might influence the use of the metadiscourse in their writing. Unimus EFL learners are familiar with the use of interactive metadiscourse, such as transition markers and code glosses in which the frequency of occurrence could be clearly seen in Table 3 . It is different from interactional metadiscourse in which the number of it is only about quarter of the use of interactive metadiscourse.

\section{CONCLUSION}

Based on the data analysis, metadiscourse markers used by EFL learners of Unimus in writing introduction sections happen with the illustration of 1 discourse marker is used in 8.42 words. The most frequently use of metadiscourse markers happens in the interactive dimension in which there are 524 markers $(82.3 \%)$ which are mainly dominated by the use of transitions with the amount of 374 markers (71.4\%) and followed by code glosses with 70 markers, evidentials (33 markers), frame markers (20 markers) and endophoric markers (27 markers). In the interactive dimension, from the total of 5.363 words produced by the learners, it could be said that 1 discourse marker is used in 10.23 words.

Conversely, in the interactional dimension, only 113 markers $(17.7 \%)$ could be found in the learners' writing which comprises hedges with the highest occurrence of 39 markers, and it is followed by self-mentions with 21 markers which are equal with boosters (21 markers), attitude markers achieve 15 markers, and engagement markers have 17 markers. It means that in the interactional dimension, 1 marker is used for 47.5 words.

From both interactive and interactional dimensions, the frequent use of metadiscourse markers happens in the interactive metadiscourse. It means that the writers tend to give attention to and guide the readers through the text by establishing their interpretations explicitly rather than involving the readers in the argument through using markers in interactional dimension.

Considering the importance of metadiscourse markers in academic writing, the lecturer of writing subject should give more 
attention to the teaching and applying the use of metadiscourse markers including interactive and interactional resources in writing class. The interactional markers should also be taught to the students in order to help them in conveying and strengthening their own argumentation. Without giving knowledge of metadiscourse markers, the learners will get difficulties in building communication and making negotiation with the readers through the texts created, and determining their judgment in their writing.

By recognizing metadiscourse markers, it is expected that the students understand better the distinction between old and new information in sentences so that they would have better understand writing. The students are also expected to be able to guide the readers by providing their interpretations explicitly and involving the readers through the text. The further research is also expected to be conducted by other researchers in other fields to have a distinction between the use of metadicourse markers in qualitative study and quantitative study.

\section{REFERENCES}

Anwardeen, N. H., Luyee, E. O., Gabriel, J. I., \& Kalajahi, S. A. R. (2013). An analysis: The usage of metadiscourse in argumentative writing by Malaysian tertiary level of students. English Language Teaching, 6(9), 83-96. doi: 10.5539/elt.v6n9p83.

Cao, F., \& Hu, G. (2014). Interactive metadiscourse in research articles: A comparative study of pragmatic and disciplinary influences. Journal of Pragmatics, 66, 15-31. doi: 10.1016/j.pragma.2014.02.007.

Dafouz-Milne, E. (2008). The pragmatic role of textual and interpersonal Metadiscourse markers in the construction and attainment of persuasion: A cross-linguistic study of newspaper discourse. Journal of Pragmatic, 40, 95-113. doi: 0.1016/j.pragma.2007.10.003.
Dehghan, M., \& Chalak, A. (2015). Code glosses in academic writing: The comparison of Iranian and native authors. IJRELT, 3(2), 21-29.

Hyland, K. (2010). Metadiscourse: Mapping interactions in academic writing. Nordic Journal of English Studies, 9(2), 125-143.

Hyland, K. (2015). Metadiscourse. The International Encyclopedia of Language and Social Interaction. Retrieved from https://www.researchgate.net/profile/Ken_Hyla nd/publication/285591598_Metadiscourse/links/ 59ddf79d0f7e9bec3bae06ad/Metadiscourse.pdf.

Hyland, K., \& Tse, P. (2004). Metadiscourse in academic writing: A reappraisal. Applied Linguistics, 25(2), 156-177. doi: 10.1093/applin/25.2.156.

Kuhi, D., \& Mojood, M. (2014). Metadiscourse in newspaper genre: a cross-linguistic study of english and Persian editorials. Procedia, Social and Behavioral Sciences, 98, 1046-1055. doi: 10.1016/j.sbspro.2014.03.515.

Rustipa, K. (2014). Metadiscourse in Indonesian EFL learners' persuasive texts: A case study at English department, UNISBANK. International Journal of English Linguistics, 4(1), 44-52. doi: 10.5539/ijel.v4n1p44.

Suhono, \& Haikal. (2018). Interactive metadiscourse and interactional metadiscourse categories of students' international program school based on gender. IJEE (Indonesian Journal of English Education), 5(1), 81-91. doi: 10.15408/ijee.v5i1.5505.

Wei, J., Li, Y., Zhou, T., \& Gong, Z. (2016). Studies on metadiscourse since the 3rd millenium. Journal of Education and Practice, 7(9), 194204.

Zakaria, M. K., \& Malik, F. A. (2017). Metadiscourse in academic writing of pre-university Arab Students at the International Islamic University Malaysia (IIUM). MATEC Web of Conferences. doi:10.1051/matecconf/201815005086. 
Siti Aimah, Dodi Mulyadi, \& Muhimatul Ifadah

Metadiscourse markers written in introduction section of final project of Unimus learners 